\title{
Parental Perspectives towards the Vocational Education Training Sector in Vietnam
}

\author{
Vi Hoang Dang \\ Namdinh Vocational College, Vietnam \\ University of New England, Australia \\ hdang2@myune.edu.au
}

\begin{abstract}
The main purpose of this study is to explore the parental perspectives of the vocational education and training (VET) sector in Vietnam. The data were collected from 32 parents in the Northern and Southern regions using six open-ended interview questions focussing on the vocational education training system. Several techniques, namely word repetitions, key words in context, and similarities and differences were applied to discover the common emerging themes and sub-themes. The issues which corresponded with the six questions were (1) quality and types of VET input, (2) VET teachers' ability, (3) facilities and equipment, (4) the relationship between VET providers and industries, (5) recognition of VET qualifications and (6) job potential. The results indicated two main positive and negative themes emerging in five of the issues, the exception being the relationship between VET providers and industries. The issue of job potential was evaluated positively by parents. However, the findings indicate wastage of trained manpower due to the weak relationship between VET providers and industries. The recommendations are that Government agencies should be more involved in the VET sector by providing teaching protocols and implementing policy concerning two-way collaboration between VET providers and enterprises, making the sector more attractive to parents, students, industries and other key stakeholders with the primary aim of changing perceptions of the VET sector positively.
\end{abstract}

Keywords: Vocational education training sector, parental perspectives, Vietnam, open ended questions

\section{Introduction}

Vietnam aims to move from being a simple agricultural-based economy into a modern industrialized economy by 2020. To make the transition successfully, the Government has recognised skilled manpower as the key factor in reaching this goal (DGVT, 2011). To achieve industrial nation status by 2020, the Vocational Education Law was passed by the Vietnamese Congress in 2006, identifying the VET system as an alternative education pathway to producing a skilled workforce. The establishment of a nationwide network of VET institutions demonstrates significant governmental efforts to promote skills-based education for Vietnam's future generations. Recent statistics (GDVT, 2011) show that the VET network has 1,293 registered providers including 136 vocational colleges, 308 vocational secondary schools and 849 vocational training centres. From 2006 to 2011, VET providers produced over 1,300,000 skilled workers with training lasting typically between 12 and 36 months. In the period from 2006 to 2011, a further 7,000,000 workers were produced during short-term vocational training courses lasting between 3 and 12 months. According to GDVT (2011), over 80\% of students were successful in gaining employment immediately after graduation. In 2010, the GDVT (2011) reported that employment rates in the welding, automotive, and electrical divisions were approximately $90 \%$. The VET sector is made more attractive by its good salaries. In the technical fields such as electrical, welding, computing and mechanics, vocational graduates were paid $10 \%$ more than academic graduates.

However, Confucian ideology still influences thinking in Vietnamese society, and academic vocations are much more respected than others (London, 2011). Many consider vocational education an 'opt-out' suitable for delinquents, the lower class and blue collar workers, and similar persons. However, there are emergent signs of significant cultural and societal changes that may positively influence future attitudes towards and opinions of the VET system. Increasing engagement with globalization and internationalization are central to developing the country's economy. Since the introduction of the 'DoiMoi' or 'Open Door' policy in 1986, Vietnam has promoted itself as a friend to all other countries in the world. Not only in developing countries like Vietnam but also in developed countries such as the United States and European countries with the exception of Germany, vocational education and training has a low image, especially from the perspective of parents (Dang \& Hathaway, 2014). Parental perception has a strong influence on a child's career choice (Reese, 2001). When parents view an occupational program as an educational program and not as a vocational program, they more easily 
accept it as a valid educational option for their children. Parents who view career vocational education as a quality route, but just not suitable for their child, begin to change their opinion when statistics exist to document the academic success of students who have taken career technical courses. When this happens the negative stigma begins to fade (Reese, 2001). A child's desire to learn is a goal that parents, educators, and communities can all agree upon. If parents begin to see career vocational education as a tool that can help achieve that goal, they will no longer view it negatively and will begin to see it as an essential component of a well-rounded education for anyone's child (Reese, 2001). In a study performed by the Oneida-Herkimer-Madison Board of Cooperative Educational Services in Hartford, New York (2007), it was found that $58 \%$ of respondents who had participated in career technical education said that a parent or guardian influenced them to undertake this education path, while $16 \%$ of the students not participating in career technical education said that a parent or guardian influenced their decision. It is thus important for career vocational education marketing strategies to reach out to parents and guardians to ensure they are informed about career vocational programs and their potential benefits (Palmer, 2007). The influence of parents and guardians is significant and must be addressed if enrolment in vocational education is to flourish (Gaunt \& Palmer, 2005).

Research problem: There are a variety of challenges affecting the effectiveness of the VET sector, both in Vietnam and internationally, which are widely accepted (GDVT, 2011). Some of the key challenges include the mismatch between acquired skills and market needs, widespread concern about poor quality training and training environments, and negative public attitudes and perceptions regarding vocational education and training (Atchoarena \& Delluc, 2001). With the implementation of the new Vocational Law 2006 in Vietnam, it is imperative to understand the nature of these attitudes and perceptions to be able to target effective interventions that will improve and promote the sector. This paper presents the evidence or evaluations from the parental perspectives of the VET sector. In the Vietnamese context, parents have been seen as the most important persons who influence the future career choice of their children. With this information, GDVT can develop interventions that improve VET delivery, recognise the benefits of training and what the market worth of VET trained persons is perceived as being.

Research question: What are the parental perspectives of the VET sector?

\section{Methodology}

Sampling: The research was conducted in the two main regions of Vietnam. In the Northern region, three provinces namely Namdinh, Ninhbinh and Haiduong were selected based on the lead researcher's knowledge of the area. In the Southern region, the three provinces chosen were Dongnai, Binhphuoc and Vungtau. Parents who participated in the survey were targeted because they have children studying in years 9 or 12 or at vocational schools.

Instrument: This paper covers the second phase of the project which explores the key stakeholders' perceptions of the VET sector. In the first phase, quantitative survey questionnaire data were analysed statistically by SPSS software version 19 to explore current students' perception of the VET image that was represented by seven dimensions, namely: entry requirements, facilities and equipment, teachers' ability, recognition of qualifications, career and job potential, quality of curriculum, social values and soft skills. The findings of the first phase indicated that students' positive perceptions of the VET image included facilities and equipment, teachers' ability, quality of curriculum, and social values and soft skills (Dang \&Hathaway, 2014). The results also revealed the dimensions of quality of curriculum and entry requirements impacted significantly on students' intention to pursue the vocational education training programs. In the second phase of the study a qualitative research methodology was adopted using an interview protocol involving six open ended questions exploring the parental perspectives of six issues, namely (1) quality of VET input; (2) VET teachers' ability; (3) VET facilities and equipment; (4) linkages between VET providers and industries; (5) recognition of VET qualifications; and (6) job potential of the VET sector. The questions (see appendix 1) were designed based on the seven dimensions that represented the VET image in the previous phase (see chart 2) combined with findings from the General Directorate Vocation Training (GDVT, 2011). For the purpose of this paper, only the findings of the second phase are presented.

There were two primary considerations in selecting open-ended interview questions as the means of data collection. Firstly, the set of questions focuses on only one topic (the image of VET) and could be prepared in advance. Secondly, open-ended questions allow participants the freedom to express their views in their 
own words and in their own time, in a place of their choosing (Kendall \& Kendall, 2002). The third phase of research involved nominal focus group discussions to unpack other key stakeholders' perception of the VET sector. In addition, ways to improve the VET image were discussed (to be reported in the next research paper). The results from the quantitative survey questionnaire, open-ended questions, and nominal group technique will be compared to see if similar results emerge. If the conclusions from each of the methods are the same, then validity is established (Mays \& Pope, 2000) (see figure 1).

Figure 1: Data triangulation method

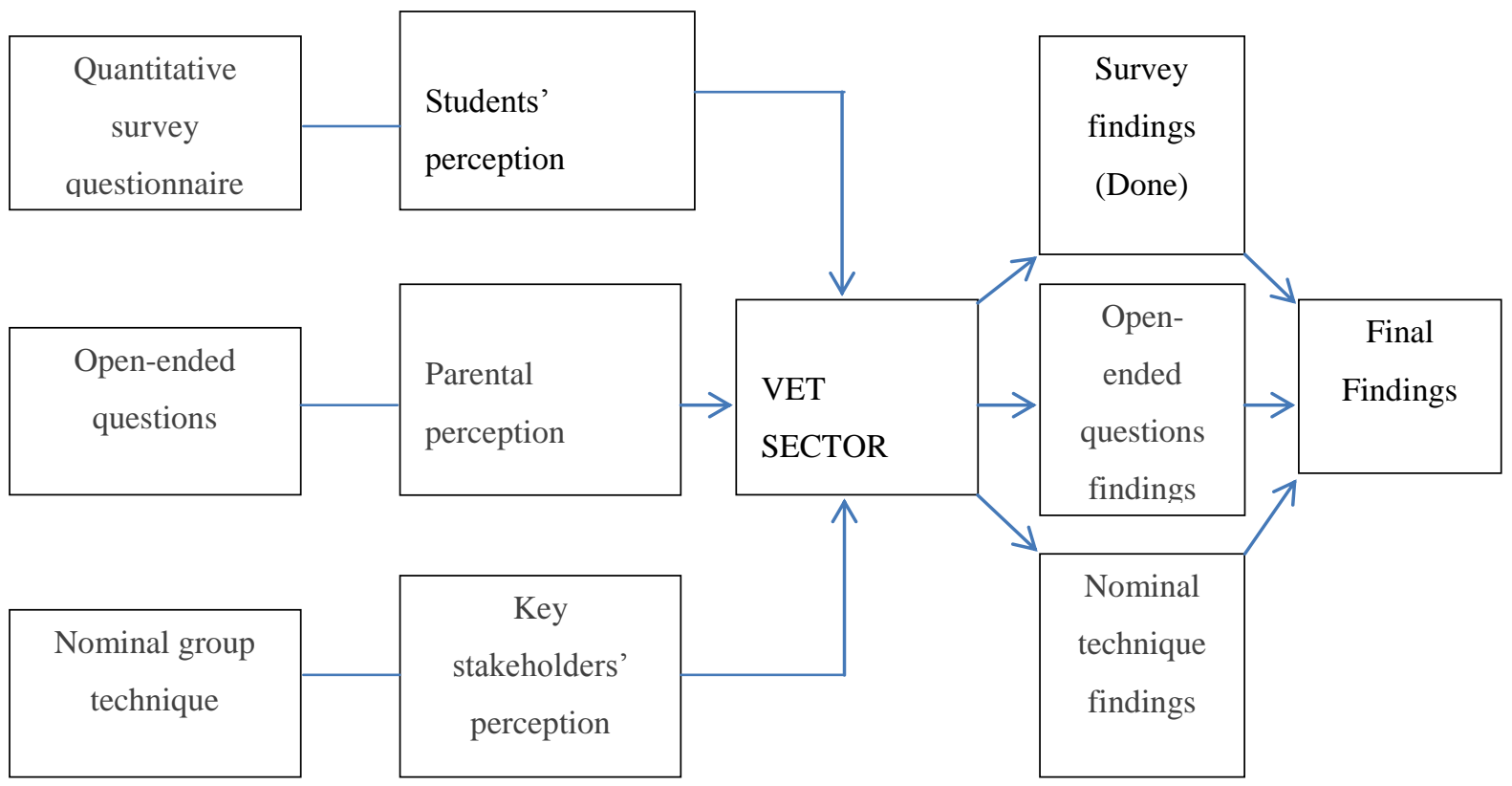

Procedures: Collecting and recording data from open-ended questions can be done in various ways. The method employed in the present study was to prepare a paper-based form (see appendix 1) which lists all six open-ended questions for parents to answer and complete. The principal advantage of this strategy is that it allows plenty of time for parents to answer the questions. However, lack of opportunity to observe the feelings of parents about the topics and further explanation of the questions are acknowledged limitations (Kendall \& Kendall, 2002). The completed forms were collected two weeks after distribution and were translated immediately into English. Data pertaining to each question were entered into separate Excel spreadsheets. A thematic analytical framework was applied to analyse data in line with the inductive approach. An inductive approach is used in qualitative research to augment understanding of complex data using summary themes or categories from the raw data (Thomas, 2003). It is noted that the parents' answers in the following analysis reflect the actual transcripts as closely as possible, with minor editorial changes to make them more readable. The responses from the questions were grouped into three domains to explain the viewpoints of parents concerning VET programs. In each domain, there were issues describing the detailed aspects of the VET sector. According to Ryan (2003), there are twelve techniques used to create themes and sub-themes. In this study, three techniques, namely (1) word repetitions, (2) key words in context, and (3) similarities and differences were applied to determine the common emerging themes in each issue. The next step was to identify sub-themes that link the research findings and the research questions through data analysis. Data are compiled by gathering them in the poles, themes and categories to understand the meaning of a phenomenon.

Respondents' background: Table 1 describes the background of parents in the Southern and Northern regions who participated by responding to the six open-ended questions in the period from 10 March to 10 April, 2014. The goal was to meet a quota of fifty parents who have children enrolled in year 9 and year 12 and in vocational schools in the previous phase (quantitative survey questionnaire); these parents were formally invited to answer the open-ended questions. Thirty-two parents responded; eighteen parents came from three provinces: Namdinh, Ninhbinh and Haiduong in the North, and fourteen parents were from Dongnai, Binhphuoc and Vungtau provinces in the South. Eight parents were over 50 years of age, eighteen parents were aged from 40 to 50, and six parents were from 38 to 39 years old. Three parents were graduates at Master level; 12 respondents had a Bachelor level education, eight parents had diploma or advanced diploma qualifications, and nine parents had lower or upper secondary 
certificates. There were eight parents who have jobs in the education sector and are working as lecturers or teachers, six parents worked in the public sector as officers, seven parents worked as technicians and skilled workers and six participants were farmers. Three parents were businessmen or women, one parent was a policeman and one parent was unemployed.

Table 1: Respondents' background

\begin{tabular}{|c|c|c|c|c|c|}
\hline No & Region & Province & Age & Educational level & Job \\
\hline 1 & North & Namdinh & 52 & Master & Lecturer \\
\hline 2 & North & Namdinh & 42 & Advanced diploma & Officer \\
\hline 3 & North & Namdinh & 38 & Bachelor & Teacher \\
\hline 4 & North & Namdinh & 44 & Graduated year 12 & Farmer \\
\hline 5 & North & Namdinh & 39 & Advanced diploma & Officer \\
\hline 6 & North & Ninhbinh & 41 & Bachelor & Officer \\
\hline 7 & North & Ninhbinh & 52 & Graduated year 12 & Farmer \\
\hline 8 & North & Ninhbinh & 46 & Advanced diploma & Skilled worker \\
\hline 9 & North & Ninhbinh & 39 & Bachelor & Teacher \\
\hline 10 & North & Ninhbinh & 39 & Diploma & Technician \\
\hline 11 & North & Ninhbinh & 51 & Bachelor & Teacher \\
\hline 12 & North & Ninhbinh & 47 & Graduated year 12 & Worker \\
\hline 13 & North & Haiduong & 56 & Graduated year 9 & Farmer \\
\hline 14 & North & Haiduong & 47 & Bachelor & Officer \\
\hline 15 & North & Haiduong & 42 & Diploma & Worker \\
\hline 16 & North & Haiduong & 50 & Bachelor & Officer \\
\hline 17 & North & Haiduong & 43 & Graduated year 9 & Farmer \\
\hline 18 & North & Haiduong & 51 & Master & Teacher \\
\hline 19 & South & Dongnai & 42 & Advanced diploma & Technician \\
\hline 20 & South & Dongnai & 45 & Graduated year 12 & Farmer \\
\hline 21 & South & Dongnai & 50 & Graduated year 12 & Farmer \\
\hline 22 & South & Dongnai & 47 & Bachelor & Policeman \\
\hline 23 & South & Dongnai & 39 & Advanced diploma & Technician \\
\hline 24 & South & Dongnai & 54 & Bachelor & Teacher \\
\hline 25 & South & Binhphuoc & 40 & Diploma & Skilled worker \\
\hline 26 & South & Binhphuoc & 48 & Graduated year 12 & Unemployed \\
\hline 27 & South & Binhphuoc & 46 & Bachelor & Business man \\
\hline 28 & South & Vungtau & 39 & Bachelor & Officer \\
\hline 29 & South & Vungtau & 41 & Bachelor & Teacher \\
\hline 30 & South & Vungtau & 49 & Bachelor & Business woman \\
\hline 31 & South & Vungtau & 47 & Master & Lecturer \\
\hline 32 & South & Vungtau & 48 & Graduated year 12 & Business man \\
\hline
\end{tabular}

Domain findings: Six open-ended questions have been grouped into three domains. The first domain describes the parents' evaluations and opinions of entry requirements to enter VET programs, and is called the quality and types of VET input. Question number 1 (see figure 2) provides data for the domain. The second domain comprises questions number 2, 3 and 4 and is called VET process, providing information about parental perspectives on three issues: (1) VET teachers' ability, (2) facilities and equipment, and (3) the relationship between VET providers and enterprises which enhances the knowledge and skills of VET students. The third domain covered two issues, namely recognition of VET qualifications, and job potential. Questions 5 and 6 deliver data for this domain, which reflect the parents' viewpoints of the outcomes of the VET sector.

Domain 1: Quality of VET input: Domain 1 describes parents' evaluation of the quality of students enrolled in VET programs, and types of current VET students. The parental perceptions were divided into positive and negative themes.

Positive theme: There were two positive points from the parents' point of view concerning the quality of VET input. The first is that parents from the Southern region believe that students enrolled in the VET sector could study successfully to gain skills from basic to advanced levels from VET providers even if they had a poor academic record. They explained that an outcome of vocational study is to produce a 
skilled workforce and not for the purpose of research, so lower achieving students could undertake the curriculum of the VET providers and become skilled workers after completing the VET course.

"Generally, students who enrolled with VET providers can study successfully and will achieve at a range of levels. At VET schools, students are taught in a hands-on way, and do not spend too much time on the theory." (Mother, South)

\section{Figure 2: Students' and parents' VET sector Perception Framework}

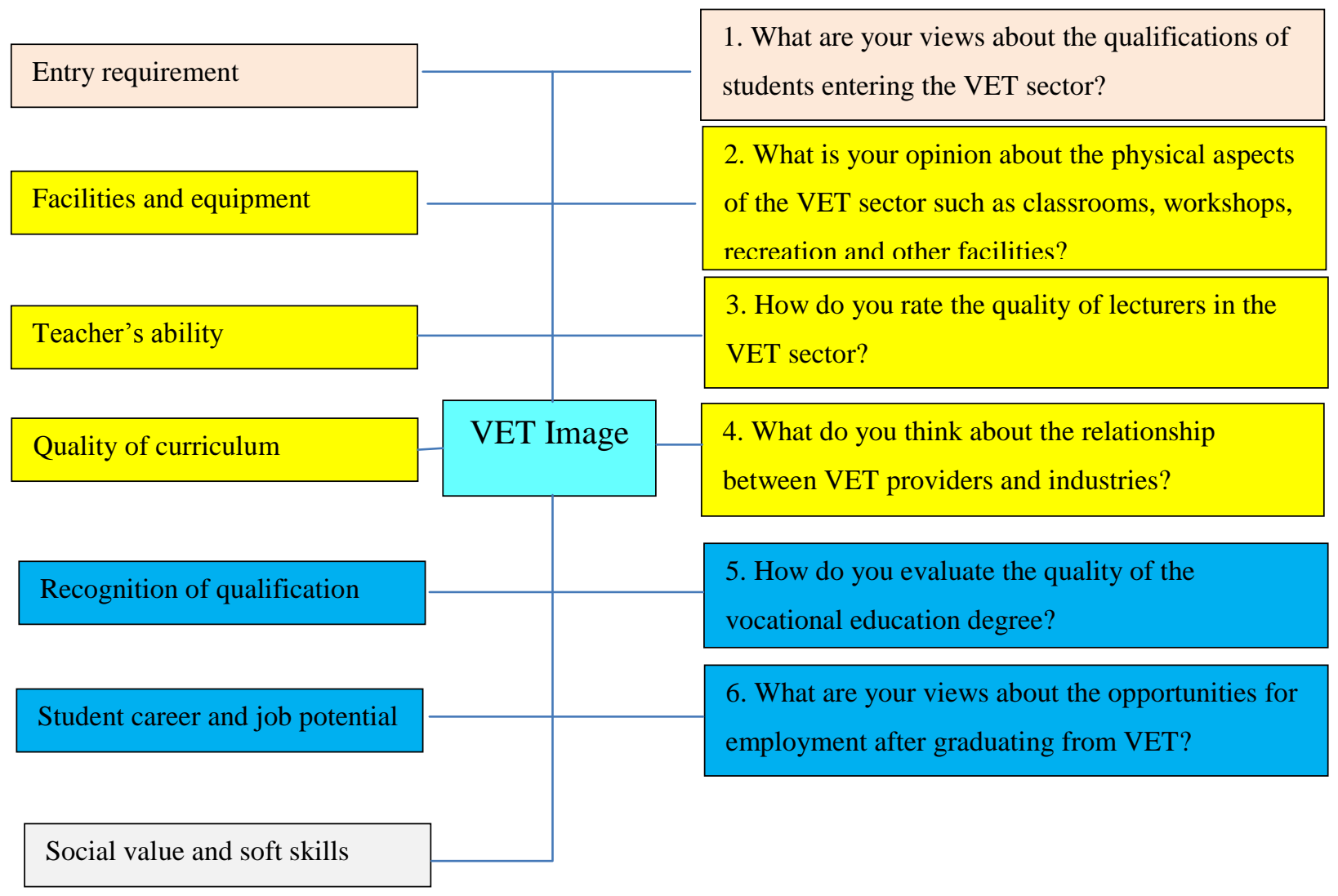

The second positive point depicts the parents' belief that VET students are more creative and interested in practical aspects. Parents pointed out that studying theory can be boring, time consuming, and not interesting. They also believe that practical lessons trigger the students' creative abilities and promote interaction with other students.

"VET students do not have enough patience to study academic subjects. However, they become actively and innovatively interested in practical lessons." (Mother, North)

Negative theme: Overall, parents in both Northern and Southern regions had a negative perception of entry requirements and types of students enrolling in VET programs. This theme is grouped into three sub-themes to describe the viewpoints of parents on the issue. The first sub-theme associates VET students and low academic results. There was consensus of parents in both Northern and Southern regions that only students who achieved average and poor results enrolled in VET programs. Parents believed that these were students who did not pass the examination to go to year 10 of upper secondary level (year 9 students),or failed to get a place in university (year 12 students), and that they had limited avenues for the future, so registering in the VET sector was a good option, even a last resort for them. "Students who enrolled in the VET sector had poor results in the lower or upper secondary schools. They didn't get enough marks to pass the examination at the end of year 9 to go to year 10, or did not pass the university entrance examination. As a last resort, they entered the VET sector." (Father, South)

The second sub-theme was the parental view that VET students frequently came from a lower economic status background, from mountainous or rural areas, or there were other specific, extenuating circumstances. One of the mothers from the North said that "Students joining VET programs were mainly from difficult economic status families and from rural areas. There were only small numbers of students from urban zones entering the VET sector, their main motivation being to avoid recruitment into the 
army, or to study temporarily in the VET sector while waiting for the next university examination."(Mother, North)

The last sub-theme focussed on the premise that VET students do not understand clearly the way to select a career or had insufficient or poor guidance. Parents said

"Students who enter the VET sector did not have enough information about the VET sector from the career guidance counsellor in the school, or advice from their relatives, especially their parents." (Father, North)

Also, parents indicated that

"Students did not make a confident choice. They just enrolled in VET programs because they were following their friends or had no other opportunity for study after they failed the university examination."(Mother, North)

Discussion: An emphasis on mainstream academic education in Vietnamese society has disadvantaged current VET students as well as those students who would like to enrol in VET programs, and the limitations in career guidance and weak implementation of the policy of streaming lower-achieving students at the end of year 9 to VET providers are two main reasons explaining why VET students receive negative perceptions from society and parents, discouraging other students from VET programs. The first reason is the excessive focus on the academic aspect of education adopted by all classes of society in Vietnam, especially by parents. 'It is widely accepted that from primary through to secondary education levels that the main processes of the school such as the teaching method of the teachers, the learning process of students and assessment of students focuses predominantly on the goal of gaining good marks and passing the university entrance examination (Nguyen, 2014). In addition, parents are competitive in wanting their children to achieve good results at school. Other skills and interests of their children are neglected and seen as unimportant. This is also seen as a reason students neglect considering VET programs. Also, parents often promote examples of excellent academic students for their children to follow, but they rarely mention students who are successful in skilled jobs or trades (Cao, 2015).

The second reason is guidance counsellors' limited knowledge about VET programs, and the unsuccessful implementation of policies for streaming secondary students (GDVT, 2011).The understanding of the VET system by guidance counsellors at secondary schools is weak and confused. Vice director of GDVT, Cao(2015) has recognized that the staff and teachers at vocational training institutions, and guidance counsellors at secondary schools do not understand fully, nor know clearly, the content of VET programs necessary to advise and inform their students. From the student's perspective, according to Mori (2014), high school students are really hungry for information about the VET sector and are insufficiently advised of the number of programs that are available through VET providers, and are not made familiar with updated information about the labour market. A survey conducted by MOET (2012) indicates that 57\% of 30,648 respondents found information for choosing a career independently (Hoang, 2010) without the assistance of a career guidance counsellor.

As far as the policy of streaming of year 9 students is concerned, the implementation was unsuccessful (GDVT, 2011). There were only approximately $2 \%$ of year 9 students going into the VET sector. According to the Vice Minister of MOET (Bui, 2013), three main explanations describe the failure of the streaming policy. Firstly, knowledge about VET programs by individuals, schools and society in generalize limited. Secondly, students and their families do not themselves fully understand the ramifications of the academic ability of their children, and even their economic position. If they understood fully these situations, they could see that vocational education may be a good way for them to reduce the stress of the financial issue and be able to enter the labour market earlier. Finally, the labour market information system is poor and not updated regularly. In conclusion, this domain revealed two positive and three negative points concerning parental perspectives of the quality and types of VET input. The negative perceptions from parents on the aspect of the low quality of VET input concur with those in the report of the Asian Development Bank (ADB). This report warned the Vietnamese Government, economists and educators that 'pushing low-performing students into technical and vocational training may yield lowquality graduates and result in employers devaluing these programs" (ADB, 2013).

Domain 2-The VET process: This domain is comprised of three issues that influence the acquisition of skills essential for VET students. These are teacher's ability, facilities and equipment, and the relationship between VET providers and enterprises. 
Ability of the VET teacher: As with the aspect of quality of VET input noted in domain 1, parents were divided in their points of view regarding the ability of VET teachers.

Positive theme: Among 32 interviews, there were only two positive comments with regard to the ability of VET teachers. The first arose from the fact that the qualification of VET teachers had been standardised to meet the requirements of the teaching professionals in the GDVT and VET institutions. According to Vu (2013) "generally, the VET teachers have met the standard GVDT requirements of the teaching process in both academic knowledge and practical skills". The statement from GDVT (2011) is in line with the view of a parent who happens to work in the VET sector. He explains that at the moment, to become academic VET teachers, the minimum qualification must be a bachelor degree. In addition, following employment in the sector, not only a teaching certificate but also certificates of foreign language and information must be added. Some teachers who teach practical sessions are recruited and selected from highly skilled workers and artisans. In the view of the parent, only the theoretical or academic skill of the VET teacher was evaluated highly.

The other positive points concerning VET teachers were enthusiasm for and responsibility in their job. One of the parents who had studied in VET programs previously said that

"VET teachers have a high responsibility in conveying not only academic skills but also soft skills to their students in the class." (Mother, South)

Parents were also very impressed with the way that VET teachers worked diligently with students when they were in practical lessons. It is noted that in these evaluations VET teachers were compared favourably with lecturers in the higher education sector.

"Vocational teachers were more enthusiastic and responsible than the university lecturers. They live simply and ethically."(Father, North)

This positive point of view was in line with the Vu (2013) study.

"Almost all VET teachers are dedicated to their teaching and training job and have good ethics".

Negative theme: However, in contrast to the previous observations, parents generally had negative evaluations of VET teachers' ability. These evaluations were grouped in to two sub-themes. The first subtheme was the limitation and weakness in practical skills of VET teachers which was mentioned in almost $85 \%$ of the evaluations of the 32 parents surveyed. The parents explained that VET teachers had either good academic or good theoretical skills. This evaluation fits well with the positive point mentioned above. However, the teachers had not had sufficient experience practising skills in the workshop during their own study period at university, nor had they had opportunities to enhance their practical skills in industry in their time working in the VET school. Parents also indicated that VET teachers focus more on theory in the classroom. In addition, the practical lessons given were not highly valued because of the teachers' inexperience and lack of expertise in the field.

"The VET teachers have good academic knowledge however they are weak and limited in practical skills because of inexperience in their field of teaching."(Father, North)

The second sub-theme was the poor response to the updating of information technology skills and the learning of a foreign language by VET teachers.

"VET teachers have good knowledge in theory. However, their foreign language and information technology skills are weak and limited". (Mother, South)

This subtheme is in line with the report from GDVT (2011) "Science research, foreign language and applied Information Technology competences among vocational teachers are still limited. Therefore, their ability to keep themselves updated with new knowledge and technology is yet to be satisfactory".

In another response, one of the parents said that

"Vocational teachers do not have an optimal or desirable motivation for acquiring good teaching methods for transmitting vocational experiences and knowledge to their students". (Mother, North)

The quotation above describes the viewpoint of a parent regarding the teaching methods needed by VET teachers in order to convey their knowledge and experience to students. Parents want VET teachers to enthuse their students and stress the worth of vocational education. This would encourage students to have more confidence in the potential of gaining employment or opening their own business at some stage in the future, using the knowledge and skills which were studied at the school. 
Discussion: Two explanations can be posited as to why VET teachers receive negative parental evaluations concerning the issue of practical skills. Firstly, there are not many current teachers who can teach both theory and practical units. In the $\mathrm{Vu}(2013)$ study, results revealed that there were only $7.05 \%$ teachers who teach at vocational college institutions who possessed a high level of practical skills, and $0.04 \%$ of artisans joining the VET sector who were competent in the teaching area. The proportion of VET teachers with high practical skills and artisans at the secondary vocational schools were $5.4 \%$ and $0.32 \%$ respectively, whereas the ratio of VET teachers teaching academic units was a high $63.4 \%$ at vocational college level, and $53.9 \%$ at secondary vocational levels.

Secondly, there are few institutions training VET teachers (GDVT, 2011). According to a report (2011) from the General Directorate of Vocational Training, vocational teachers are currently sourced from three sectors. The main source of VET teachers is from university. They have the responsibility of the transmission of academic knowledge to students, and unfortunately their practical skills and teaching methods are limited through inexperience. The second VET teacher source is from five vocational teacher training institutions (four universities and one at college level). They have studied and are equipped with knowledge in the areas of teaching method, academic knowledge and have practical skills acquired in the industry. Their weakest point is limited or insufficient experience in industry. The last VET teacher source is from highly skilled workers and artisans. They are strong in the practical area and highly skilled in their particular field; by contrast, however, they are inexperienced in teaching method and lack academic knowledge. In conclusion, regarding the issue of quality of VET input, the aspect of the VET teacher's ability in general had a predominantly negative perception by parents. Only two positive points were noted compared with two negative sub-themes and some single negative points, pointing to the reality of the lack of expertise of VET teachers in Vietnam.

Facilities and equipment: The open ended question in the dimension of facilities and equipment also revealed two main streams. While parents believe that VET providers have acquired the basic points of teaching and understand the learning process, they evaluated VET poorly in relation to infrastructure, and commented on out-of-date equipment being used at VET schools.

Positive theme: The results in the research by Vu (2013), which focused on the evaluation of facilities and equipment used by the VET sector, correspond with the assessments from parents in the present study. There was only one positive evaluation from Northern parents.

"The facilities and equipment of the VET providers have met the requirements of teaching and learning process."(Mother, North)

The survey conducted by $\mathrm{Vu}$ (2013) revealed that only $2.3 \%$ of evaluations by VET teachers, VET managers and managers of industry considered that the facilities and equipment for teaching and learning were sufficient, whereas $83.5 \%$ participants said that these aspects of VET were inadequate.

Negative theme: Three sub-themes were emergent in this theme. The first sub-theme was poor infrastructure of VET providers. Parents had mainly negative evaluations of the facilities such as class rooms and workshops. Also, they were disappointed with other facilities affecting the standard of living and learning at the school such as the water system, electricity and toilets.

"My son, who is studying with a VET provider, said that the workshops for practical lessons are small with not enough light for teaching and practical work. The safety equipment and air ventilation system at the workshop are not installed."(Mother, South)

Another parent said that

"The water system does not meet the minimum requirements for bathing and washing. Besides, the quality of water resource is not guaranteed. The toilet was dirty and not cleaned regularly". (Mother, North)

The second sub-theme revealed that there were insufficient materials for the teaching and learning process. Parents in both the North and South had complained about this issue.

"The materials and supplies for practical lessons are not enough for the students to work with". (Father, North)

The third sub-theme identified concerned the old and outdated practical equipment. One of the parents from the South said 
"The equipment for practical teaching is out of date; some machines from 1950 are still being used for teaching. They are neither compatible with nor suitable for the reality of modern manufacturing". (Mother, South)

Discussion: The results of the open-ended question concerning the issue of facilities and equipment were compared with the Vu (2013) study and the GDVT (2011) report. The first similarity in all three studies (present study, Vu (2013) study, and GDVT (2011) report) was the low level of positive evaluation of the facilities and equipment available to the VET sector. In the present study, only one parent said that 'the facilities and equipment of the VET providers have met the requirements of the teaching and learning process". (Mother, North). The results shown by Vu (2013) revealed only $2.3 \%$ of participants agreed that the infrastructure and equipment available was sufficient for good teaching and learning experiences. The report from GDVT said that 'a small percentage of VET institutions are sponsored by core occupations or receive funding from the Official Development Assistance (ODA) or the National Target Program and hence are equipped with modern equipment on par with regional standards' (GDVT, 2011).

The Government of Vietnam has made large investments into the VET sector for the purpose of changing social perceptions especially of parents and in the hope of attracting students to VET programs. This is evidenced in the funding records for the sector which demonstrate an increase annually, and tenfold, from 49 million USD to 490 million USD, in the period from 2001 to 2011. Notably, 40 of the 1293 VET providers in the network across the country have received these massive investments from National Target Program with the aim improving their facilities to meet the regional standard requirements (GDVT, 2011). The expectations of Government are that funding will have a positive impact and attract greater numbers of skilled workers, increasing from 23.5 million in 2015 to 33.4 million by 2020, to join the Southeast Asian labour market in 2015.The reason why only 40 VET institutions received the immense Government funding while over 1200 institutions did not benefit was not mentioned in the report. However, this fact offers an explanation as to why the issue of facilities and equipment received such a small percentage of favourable evaluation.

Consequently, the second similarity in the three studies is the high proportion of negative evaluations concerning the issue of out-dated or lack of equipment of VET institutions. The GDVT (2011) report recognized that equipment is one of the crucial factors for ensuring quality of vocational training provision. At present, however, this is still lacking and out-of-date equipment is the norm in almost all vocational institutions'. The parental view that the equipment for practical teaching is out-of-date, and the observation that some machines from 1950 are still being used for teaching support this. The results of the research by $\mathrm{Vu}$ (2013) revealed $83.5 \%$ of participants agreed that facilities and equipment currently provided are not adequate for effective teaching and learning. The third similarity is found in the negative evaluation by parents and also contained in the GDVT (2011) report in regard to the area of the class rooms and workshops of the VET providers. Parents reported that the workshops for practical lessons are small and there is insufficient light for teaching and practising skills. The GDVT (2011) report recognized that 'the practical workshops for students are yet to meet the training needs, with a very small floor area which is inadequate for installing equipment and arranging work-place seats for students; and they do not satisfy standards in construction design such as lighting, fire safety, ventilation or load standards'.

There is one inconsistency noted between the DGVT (2011) report and parental views in the present study concerning the issue of the facilities and equipment component of the VET sector. Parents detailed that there were not enough materials for students for practical work in subjects such as welding and the automotive field. The DGVT report did not comment on this issue. Vu (2013)noted that 'VET providers have focused primarily on building up programs which have lower funding requirements such as financial and economic occupations and information technology programs, whereas occupations in the automobile industry and mechanical careers with high demands from industries are receiving less government funding'.

Linkages between VET providers and industry: In the view of parents participating in the survey, responses concerning the issue of a two-way relationship between VET providers and industry fell into three categories. The first category identifies a weak connection between VET providers and industry. "Currently, businesses and vocational schools are not linked to each other. There are not common voices in the process of vocational education training."(Father, South) 
"The cooperation between enterprises and vocational schools is limited. Vocational schools are failing to meet the demands from businesses in both quality and quantity of VET outcomes."(Mother, North)

"Presently, there are only weak links, even no links between vocational training institutions and enterprises. In the future, I would like to see close links between the two stakeholders, and the link bonded through policies and mechanisms."(Mother, North)

The loose relationship between the two stakeholders is explained in two ways. The first reason is the macro management by government. There are no uniform principles or detailed policies by the Government concerning the relationship. According to Vocational Law 2006, chapter 5, article 55, Government merely encourages the relationship between VET providers and enterprises. There are not any policies or detailed mechanisms that specify the rights and responsibilities of each stakeholder. Vice director of General Directorate Vocational Training (Tran, 2009) acknowledged that 'the partnership between VET providers and industries has been established but not closely. Businesses have not paid sufficient attention to cooperation with VET schools. On the other hand, VET schools are not actively building up relationships with industry. The policies are not uniform and the ways of encouraging cooperation not established'. The second reason is the tenuous relationship between VET schools and industries. The VET institutions teach using their available programs and their current (not updated) facilities. The results are that the VET graduates do not meet the requirements of industry. The VET outcomes are not consistent with industry requirements. On the other hand, industries are not sufficiently involved in designing the curriculum, specifying content or participating in evaluations of VET providers (Tran, 2009). With the current situation, industries have the advantages in that they can have the benefit of trained employees with no obligation to make contributions in return to the VET providers.

The second category is the clear awareness of parents of the importance and benefits of a healthy twoway relationship between the two key stakeholders.

"Vocational schools and businesses working together provide opportunities for students to access the world of efficient work."(Mother, South)

"It is necessary to have the cooperation of vocational schools with businesses become closer through specific policies. It enables students to practise skills while studying at vocational schools and have the opportunity to find a job in the future".(Father, North)

"It is necessary to build up the cooperation between vocational training institutions and business enterprises. There should be policies and appropriate mechanisms to facilitate business and vocational schools having a dynamic relationship in a spirit of cooperation for the mutual benefit in both groups."(Mother, North)

According to Nguyen(2015), who is the Chairman and CEO of Neway Group Company in Vietnam, a good working relationship between vocational training and industry is now an objective and a necessity in the context of Vietnam having joined the World Trade Organisation from 2007, and with the serious current imbalance of labour requirements and lack of a skilled workforce. This is based on the economic law of supply and demand to ensure mutual benefits for both parties. Ensuring that vocational training institutions are associated with industry will improve the quality of vocational education training. The quality of vocational education training is enhanced due to the necessity to appropriately adjust programs to comply with the requirements from industry; students will have more real time for experience within the industry, the classroom input of the VET provider will be more accurate and appropriate as a result of participation in the process of industry expertise, and most importantly, teachers will increase and improve their practical capacity as well as have opportunities to access modern machinery and new technology.

The major benefit of the cooperation between industries and VET providers is the assurance of skilled human resources for the company. The second benefit is partnership; businesses will have the assistance and availability of consultancy of good teachers in addressing difficult situations that can arise in the production process. In addition, industries can reduce the cost of training and retraining their workers, thereby increasing the financial prospects of the business. The third category is the expectation by parents that there will be comprehensive cooperation between the two key stakeholders and that this will be effected through the policies and mandates of Government. These expectations are evident as parents point out the ineffective relationships of the three key stakeholders. Of the Government role in 
the relationship, one of the parents from the South said that 'at the moment, there are not any policies or detailed instructions from Government to develop the cooperation in law between the two sides'. This statement from a parent is in line with the study by Tran (2009). 'We haven't got the mechanisms to bond the two-way relationship between vocational training institutions and industries for the undertaking of training with VET providers, or industrial based training at industries'. Of the role of industry as a key stakeholder, parents said that 'the collaboration between schools and businesses in vocational training is low due to businesses not seeing sufficient benefits in this link'. From the VET school perspective, parents expect that 'VET schools should collaborate effectively with industries for the benefit of both sides'.

Interestingly, the expectations of parents regarding the link between VET institutions and businesses with the involvement of Government fits in well with the Triple Helix model (Etzkowitz \& Leydesdorff, 2000), which was modified from a two-way relationship between university and industry to a triadic relationship between university-industry-government. The Triple Helix relationship has been seen as the potential model for innovation and economic development in a Knowledge Society. The Triple Helix is a metaphor for university, industry, and government interacting closely while each maintains its independent identity. Based on the expectations from parents and the Triple Helix model, it is suggested that Government should be involved and act as a referee to control the two-way relationship between the other two stakeholders through the implementation of policies and other suitable mechanisms. Generally, the current relationship between the two key stakeholders is not very close, and neither has formulated possible common points because there are no clearly defined responsibilities and rights of each. In fact, VET schools are teaching the programs they have designed whereas the requirements from industries are quite different from what students are learning at the schools. Therefore, it is desirable and necessary to have the participation of Government as a referee to control the relationship through legislation and policy.

\section{Domain 3: VET outcomes}

Recognition of VET qualifications: The first issue arising from the VET outcomes domain of the survey is the recognition of VET qualifications. This domain looks at the values and skills VET holders acquire through VET provider education. The responses from parents to the interview question were grouped into negative and positive themes

Positive theme: Parents have recognized the importance and high demand for a trained human resource by service and manufacturing industries, and the need for this to facilitate Vietnam's smooth and effective transition from an agricultural economy to an industrial one.

"A skilled workforce has been highly valued in society especially in the context of industrialization and modernization of the country. The value of VET qualifications needs to be made known to all classes in society and even more to the younger generation."(Mother, North)

Parents have also recognized the high value of VET degrees. This is the primary requirement by employers for obtaining a job or for going on to further study.

"VET degrees are valuable in recognizing a basic level of achievement of vocational students, ensuring that students can enter the labour market and be able to improve and upgrade their study in the future."(Father, North)

"Practical knowledge or skills without an academic certificate is useless in seeking employment in Vietnam."(Father, South)

"The VET degree is a passport for VET students to get a job. It is also the basic qualification for those having motivations for the next step of further academic study."(Mother, North)

"The VET degrees have high value at the companies which require skilled qualifications, and have been beneficial in being selected for a job. They have also assisted in being recruited for working overseas through the contracts of skilled workforce recruitment between two Governments."(Mother, South)

Negative theme: Parents responded that the perceived value of VET degrees or VET holders has resulted in discrimination in matters such as benefits, social status and salary in Vietnamese society. The degrees are compared unfavourably with other mainstream educational qualifications. 
"Although VET certificates or degrees are recognized nationally, they are not still accepted in many businesses. There is still prejudice in the areas of social perception and there is a stigma surrounding VET qualifications. The salary of VET holders in public or government companies is always lower than that of employees with mainstream education degrees."(Father, North)

"VET degree holders find it difficult to find a job compared with applicants with qualifications from the mainstream education system. They still are discriminated against and receive negative views from society."(Mother, North)

"VET qualifications are not highly valued in society. The VET holders become merely workers in the companies. The VET degree holders are not thought worthy to be considered for promotion to high positions in society." (Mother, South)

Another parental response concerns the perceived low competence of VET holders; that the quality of the skilled workforce is not valued highly by the community and the requirements of industries are not met. "The value of VET diplomas is low and not accepted by most companies now. VET graduates are yet to meet immediately the requirements of industries. They have to retrain to acquire the other skills required by the companies before presenting themselves to the labour market."(Father, South). Obviously, parents have realized the importance of a skilled workforce in the context of Vietnam moving away from having a backward agricultural society towards the goal of a modern industrial economy by 2020. In addition, parents also pointed out the perceived discriminatory attitude of all levels of society towards the vocational training system, the gaps in wages and social status and limited opportunities for promotion in careers in the future. The concerns of how to change these perceptions in all strata of society and the best way to fill the gaps in the vocational education training system are raised. The answer is to have strong intervention by the government in the sector through policies and specific mechanisms (Tran, 2009).In addition, the VET system in general and each VET provider in particular must be reorganized in order to improve the quality of vocational education so that it meets the demands of business and industry (Cao, 2015). Students must also have a realistic assessment of their capabilities and interests and make appropriate career choices.

Job potential: One of the issues of high consensus receiving positive evaluations from parents is the potential for VET students to gain employment following study with VET providers.

"The employment opportunities for VET students after graduation are huge. There are many firms wanting to recruit employees who have been trained by VET providers." (Mother, North)

"Students who have studied at vocational schools have more opportunities and find it easier to get jobs than main stream education graduates and unskilled workers."(Father, South)

"VET students have a chance to work not only for domestic companies but also for international enterprises in Vietnam and overseas."(Mother, South)

However, parents also indicated that the issue of job potential has some disadvantage as a consequence of the type of job available to VET students.

"After graduation from VET schools, students have many high opportunities to get a job; however, they just are workers with a low salary."(Mother, North)

"Graduated students of vocational schools are now receiving employment in mostly unskilled jobs in industrial enterprises. These positions are not commensurate with, or have a limited relationship with their knowledge, skills and training gained at the schools."(Father, North)

Generally speaking, parents have an optimistic outlook concerning the issue of job potential of VET students. The evaluations from parents also fit well with the GDVT (2011) report. According to this report, over $80 \%$ of students were successful in gaining employment immediately after graduation. Significantly, in 2010, the report indicated that employment rates in the welding, automotive, and electrical divisions were approximately 90\%. The results suggest that GDVT should expand the information system available to the labour market (ADB, 2013) and include an estimate of the number of the VET graduates each year in order to match available jobs with the students 'acquired knowledge and skills, thus avoiding wastage of skilled personnel. The GDVT report did not include data of percentages of VET graduates gaining appropriate jobs. 


\section{Conclusion}

Table 2: The main themes and sub themes of the VET sector

\begin{tabular}{|c|c|c|c|}
\hline Domains & Issues & Themes & Sub-themes \\
\hline $\begin{array}{l}\text { Quality of } \\
\text { VET input }\end{array}$ & $\begin{array}{l}\text { Quality and types } \\
\text { of VET input }\end{array}$ & Negative & $\begin{array}{l}\text { - Courses are adaptable and versatile, ranging from low to high skill } \\
\text { levels of training } \\
\text { - Courses are more creative and interesting - provision of practical } \\
\text { experience } \\
\text { - Low academic standard } \\
\text { - Students come from difficult economic status and rural areas } \\
\text { - Students do not understand clearly the way to make career choices }\end{array}$ \\
\hline \multirow[t]{3}{*}{$\begin{array}{l}\text { VET } \\
\text { teaching } \\
\text { process }\end{array}$} & Teacher's ability & Positive & $\begin{array}{l}\text { - Have met the standard requirements from GDVT } \\
\text { - Enthusiasm and responsibility } \\
\text { - Low standard of practical skills } \\
\text { - Slow or poor uptake in updating information technology and learning } \\
\text { foreign language } \\
\text { - Weakness and limitations in teaching methodology }\end{array}$ \\
\hline & $\begin{array}{l}\text { Facilities } \\
\text { Equipment }\end{array}$ & $\begin{array}{l}\text { Positive } \\
\text { Negative }\end{array}$ & $\begin{array}{l}\text { - Have met the necessary requirements for the teaching and learning } \\
\text { process } \\
\text { - Poor infrastructure of VET providers } \\
\text { - Not enough materials for the teaching and learning process } \\
\text { - Old and out-dated practical equipment and machinery }\end{array}$ \\
\hline & $\begin{array}{ll}\text { Relationship } & \\
\text { between } & \text { VET } \\
\text { providers } & \text { and } \\
\text { industries } & \end{array}$ & $\begin{array}{l}\text { - The clear } \\
\text { - Weak con } \\
\text { - The expec }\end{array}$ & $\begin{array}{l}\text { awareness of parents of the importance and benefits } \\
\text { Inection between VET providers and industry } \\
\text { ctations of comprehensive cooperation }\end{array}$ \\
\hline \multirow{4}{*}{$\begin{array}{l}\text { VET } \\
\text { outcomes }\end{array}$} & $\begin{array}{l}\text { Recognition } \\
\text { qualifications }\end{array}$ & Positive & $\begin{array}{l}\text { - The importance and high demand for trained personnel } \\
\text { - The value of VET degrees }\end{array}$ \\
\hline & & Negative & $\begin{array}{l}\text { - The value of VET degrees or VET holders is diminished in the eyes of } \\
\text { the community and industry } \\
\text { - The low competence of VET holders and the poor quality of the } \\
\text { potential skilled workforce }\end{array}$ \\
\hline & \multirow[t]{2}{*}{$\begin{array}{l}\text { Student career and } \\
\text { job potential }\end{array}$} & Positive & - Bright future for VET students in gaining employment \\
\hline & & Negative & - The discriminatory views of VET students by enterprises \\
\hline
\end{tabular}

Table 2 summarises the main themes and sub-themes of parental perspectives of the six issues regarding the VET sector. The total picture included both positive and negative observations; generally, the VET sector was viewed by parents in a more negative way, but with some positive highlights. More specifically, five issues divided into positive and negative themes with varieties of sub-themes. The viewpoints from parents concerning the issue of the relationship between VET providers and enterprises grouped into three main themes, describing the importance and benefits of the relationship for both the industries and VET providers. However, parents evaluated the current casual connections poorly. Therefore they expected that Government should be involved in instigating these links and exercise some control in this area by identifying clearly the responsibilities of and benefits for, each stakeholder, through direct policy implementation.

Generally, the result of the present study is in agreement with the conclusion of the study by Tushar (2013). The researcher evaluated the system of vocational and technical education in the South East Asian region including Vietnam. 'The VET sector is characterized by low enrolment, high drop-outs, poor quality of teachers, inequitable access for women and rural populations, limited private sector involvement, limitation in connections between enterprises and VET schools, and very inadequate budgetary allocations. In other words, vocational education training in South East Asia is not supporting a high economic growth rate or expanding global markets. The entire system requires fundamental review and restructuring'. Currently, in Vietnam, there are not many studies according to the international format exploring key stakeholders' perceptions towards VET sector. There was a research to investigate the students' perception towards VET sector (Dang \& Hathaway, 2014). This paper would like to add one more view from parental perspectives on the VET system. To draw fully the picture of VET system, hopefully, in the future, the perceptions of other key stakeholders who have closely relationship on VET 
sector such as VET policy makers, industries, VET lecturers, and guidance counsellors should be researched.

Acknowledgement: The authors wish to acknowledge the comments, editing and assistance with English grammar received from Dr Tanya Hathaway, Helen Gee, and Giang Thu Dangwho made invaluable contributions to our work.

\section{References}

Asian Development Bank, (ADB). (2013). Viet Nam: Vocational and Technical Education Project. Retrieved fromhttp://www.adb.org/documents/viet-nam-vocational-and-technical-educationproject.

Atchoarena, D. \& Delluc, A. (2001). Revisiting Technical and Vocational Education in Sub-Saharan Africa: An Update on Trends, Innovations and Challenges. Paris: International Institute for Educational Planning, World Bank.

Bui, V. G. (2013). Họcnghề: “Con đườngmòn” ngoằnnghèothiếu a toàn? Retrieved from http://hanoimoi.com.vn/Tin-tuc/Huong-nghiep/653147/hoc-nghe-con-duong-mon-ngoanngheo-thieu-an-toan

Cao, V.S. (2015). 'Trườngnghềkhôngtuyển sinh được do chấtlượnghạnchế'. Retrieved from: http://vnexpress.net/tin-tuc/giao-duc/truong-nghe-khong-tuyen-sinh-duoc-do-chat-luonghan-che 3134427.html

Dang, H. V. \& Hathaway, T. (2014). Vietnamese Students' Perception and Loyalty towards an Image of Vocational Education and Training. Journal of Education and Vocational Research, 5(4), 228238.

Etzkowitz, H. \&Leydesdorff, L. (2000). The Dynamics of Innovation: From National Systems and 'Mode 2' to a Triple Helix of University-Industry-Government Relations. Research Policy, 29(2), 109-123.

Gaunt, D. \& Palmer, L. (2005).Positive student attitudes toward CTE. Techniques: Connecting Education \& Careers, 80(8), 44-47.

General Directorate of Vocational Training (GDVT). (2011). Báocáodạynghề 2011. Retrieved from http://www.slideshare.net/tinhanhvy/bo-co-dy-ngh-vit-nam-2011

Hoang, N. V. (2010). Hướngnghiệphạnchế, học sinh thiếuđộnglựchọcnghề. Retrieved from http://www.bentre.edu.vn/index.php?option=com_content\&view=article\&id=973:hng-nghiphn-ch-hc-sinh-thiu-ng-lc-hc-ngh\&catid=22: tin-t-cac-bao\&Itemid=69

Kendall, K. E. \& Kendall, J. E. (2002). Systems analysis and design (5th. ed.). Upper Saddle River, NJ: Prentice Hall.

London, J. D. (2011). Education in Vietnam: Historical Roots, Recent Trends. In J.D. London (Ed.), Education in Vietnam. Singapore: Institute of Southeast Asian Studies Press.

Mays, N. \& Pope, C. (2000). Qualitative research in health care: Assessing quality in qualitative research. British Medical Journal, 320(72), 50-52.

Mori, J. (2014). Thúcđẩymốiquanhệđốitácbabênđểgiảiquyếtsựkhậpkhiễngkỹnăng: Cácchiếnlược pháttriểnkỹnăngđổimớiđểđẩynhanhsựnghiệpcôngnghiệphóacủaViệt Nam. Retrieved from http://www.jica.go.jp/vietnam/english/office/others/c8h0vm00008ze15natt/policy_paper_vn.pdf

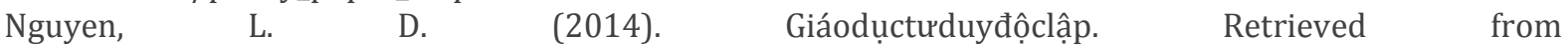
https://www.youtube.com/watch?v=_i3KK6seBoY

Nguyen, T. D. (2013). Liênkếtgiữadoanhnghiệpvàcơsởđàotạonghề: Hai bêncùngcólợi. Retrieved from http://dddn.com.vn/hoat-dong-vcci/lien-ket-giua-doanh-nghiep-va-co-so-dao-tao-nghe-haiben-cung-co-loi-20131229093553805.htm

Thomas, D. R. (2003).A General Inductive Approach for Analysing Qualitative Evaluation Data. American Journal of Evaluation, 27(2), 237-246.

Palmer, J. (2007). Measuring for marketing. Techniques: Connecting Education \& Careers, 82(2), 26-27.

Ryan, G. W. (2003). Techniques to Identify Themes. Field Methods, 15(1), 85-109.

Reese, S. (2001). Painting a positive picture. Techniques: Connecting Education \& Careers, 76(6), 20-23.

Tran, A. T. (2009). Gắnđàotạovớisửdụng, nhàtrườngvớidoanhnghiệp. TạpchíKhoahọc ĐHQGHN, Kinhtế vàKinhdoanh, 25(3), 77-81.

Tushar, A. (2013). Vocational education and training programs (VET): An Asian perspective. Asia-Pacific Journal of Cooperative Education, 14(1), 15-26.

Vu, X. H. (2013). Thựctrạngthihànhphápluậtdạynghềvàkiếnnghịcácnội dung cầnsửađổi, bổ sung vào luậtdạynghề. Retrieved from http://khcn.molisa.gov.vn/doc/Tom\%20tat\%20De\%20tai.pdf 


\section{Appendix 1: The open-ended questions}

Participant's name (optional):

Education level:

Age:

Region:

Occupation:

Province:

Question 1: What are your views about the qualifications of students entering the VET sector?

Question 2: What is your opinion about the physical aspects of the VET sector such as classrooms, workshops, recreation and other facilities?

Question 3: How do you rate the quality of lecturers in the VET sector?

Question 4: What do you think about the relationship between VET providers and industries?

Question 5: How do you evaluate the quality of the vocational education degree?

Question 6: What are your views about the opportunities for employment after graduating from VET? 